\title{
Response of Potato (Solanum tuberosum) in Medium Plains to Antagonistic Microbes and Potassium Fertilizers
}

\author{
Anis Rosyidah $^{1, *}$, Rose Novita Sari Handoko ${ }^{1}$ \\ ${ }^{I}$ Deparment of Agrotechnology Faculty of Agriculture, University of Islam Malang, Malang, Indonesia \\ *Corresponding author. Email: ard@unisma.ac.id
}

\begin{abstract}
The use of antagonistic microbes and potassium fertilizer on potato cultivation at the medium land was carried out to improve plant endurance, yield and quality. Application of potassium doses and suitable antagonistic microbial types will strengthen plant cell walls and plant nutrients to be fulfilled. This research aims to study the growth response, yield and quality of potato bulb in land medium with the application of antagonistic microbes and potassium fertilizer. The height of the land is around 670 meters above sea level, the texture of the clay and the experimental design used is the Split Plot Design. Three kinds of antagonistic microbes are A1 (Pseudomonas fluorescens), A2 (Streptomyces sp. + P. fluorescens), A3 (Trichodermaviride + Streptomyces sp. + P. fluorescens), and three types of Potassium doses are: D1 $=125 \mathrm{~kg} \mathrm{Ha}^{-1} \mathrm{KCl}, \mathrm{D} 2=250$ $\mathrm{kg} \mathrm{Ha}^{-1} \mathrm{KCl}, \mathrm{D} 3=375 \mathrm{~kg} \mathrm{Ha}^{-1} \mathrm{KCl}$. Each treatment has three replications, the number of plants per experiment plot is 22 plants, and the sample plants used in each trial plot are 6 plants. The results showed that the administration of P.fluorescens + Streptomyces sp. + T. viride and $250 \mathrm{~kg} \mathrm{Ha}^{-1} \mathrm{KCl}$ and $375 \mathrm{~kg} \mathrm{Ha}^{-1} \mathrm{KCl}$ doses tend to produce growth, tuber fresh weight per hectare, tuber dry weight percentage, tuber specific gravity and higher sugar content than other treatments.
\end{abstract}

Keywords: Solanumtuberosum L., Pseudomonas fluorescens, Streptomyces sp., Trichodermaviride, potassium, medium plain

\section{INTRODUCTION}

In the development of Potato (Solanumtuberosum L.) the availability of nutrients in the soil needs attention. The availability of nutrients can be done through fertilization. Potato plants that produce bulb require a large amount of potassium compared to other macro elements. Potassium fertilizer $270 \mathrm{~kg} / \mathrm{ha}$ can obtain the highest tuber and starch production with the desired physicochemical properties of starch [1].

Potassium was needed for potato plants for carbohydrate metabolism, enzyme activity, osmotic regulation, efficient use of water, nitrogen uptake, protein synthesis and assimilate translocation. Potassium can play a role in strengthening cell walls, involved in the process of sclerenchym tissue lignification [2]. Potassium administration causes the formation of thicker lignin compounds, so that the cell wall becomes stronger so that it can protect plants from outside influences. Potassium phosphite provides a defense response in potato through direct toxic effects on oomycetes, which can fight Phytophthorainfestans[3]. Besides potassium deficient plants, its resistance component will be disrupted so that it will facilitate pathogens for penetration [4].
Potassium is an element that dissolves easily so that it is easily leached, consequently its availability in the soil is low. Potassium deficiency can result in stunted growth, because the leaves formed are inhibited so that the process of photosynthesis is disrupted. According [5] that the role of Potassium is very important in the formation of crop yields and product quality and plant resistance. In addition, plants lacking potassium will disrupt the process of photosynthate in wheat, potato, and grapes. Potassium (K) deficiency impacts on photosynthesis through synthetic constraints of diffusion and assimilation of $\mathrm{CO} 2$ [6]. The purpose of this study was to study the response of growth, yield and quality of potato bulb in the plain medium due to the administration of antagonistic microbes and potassium fertilizer.

\section{METHODS}

The methods is divided into three types:plant material and experimental design, antagonistic microbes, analysis.

\section{A. Plant Material and Experimental Design}

This research was carried out in an endemic area of bacterial wilting at an altitude of $670 \mathrm{~m}$ above sea level, the texture of clay soil. The potato variety used is DTO-28, which is classified as a resistant variety planted on medium 
plains [7,8]. The antagonists of Trichodermaviride, Streptomyces sp., and Pseudomonas fluorescens originated from the collections of the Faculty of Mathematics and Natural Sciences, University of Brawijaya (UB), Malang, which have been selected and tested to have antagonistic abilities with pathogenic Ralstoniasolanacearum in vitro in the UB Laboratory of Pests and Diseases UB. The study was conducted experimentally using Split Plot Design. From the two treatments obtained 9 kinds of treatment combinations. Each treatment was repeated three times. The number of plants per experiment plot is 22 plants, and the sample plants used in each trial plot are 6 plants.

The percentage of tuber dry weight at harvest is calculated by the formula:

tuber dry weight $=100 \%$ - tuber water content

tuber water content $=($ fresh weight - dry weight $) /$ fresh weight $\times 100 \%$

The kinds of combination of treatments carried out in this study are presented in Table 1.

Table 1. Treatments in research

\begin{tabular}{|c|c|}
\hline Code & Doses \\
\hline A1D1 & P.fluorescens dan dosis $125 \mathrm{~kg} \mathrm{Ha}^{-1} \mathrm{KCl}$ \\
\hline A1D2 & P.fluorescens dan dosis $250 \mathrm{~kg} \mathrm{Ha}^{-1} \mathrm{KCl}$ \\
\hline A1D3 & P.fluorescens dan dosis $375 \mathrm{~kg} \mathrm{Ha}^{-1} \mathrm{KCl}$ \\
\hline A2D1 & $\begin{array}{l}\text { P.fluorescens }+ \text { Streptomyces } s p . \text { and doses } \\
125 \mathrm{~kg} \mathrm{Ha}^{-1} \mathrm{KCl}\end{array}$ \\
\hline $\mathrm{A} 2 \mathrm{D} 2$ & $\begin{array}{l}\text { P.fluorescens }+ \text { Streptomyces sp. and doses } \\
250 \mathrm{~kg} \mathrm{Ha}^{-1} \mathrm{KCl}\end{array}$ \\
\hline A2D3 & $\begin{array}{l}\text { P.fluorescens }+ \text { Streptomyces sp.and doses } 375 \\
\mathrm{~kg} \mathrm{Ha}^{-1} \mathrm{KCl}\end{array}$ \\
\hline A3D1 & $\begin{array}{l}\text { T.viride }+ \text { P.fluorescens }+ \text { Streptomyces } s p \text {. } \\
\text { and doses } 125 \mathrm{~kg} \mathrm{Ha}^{-1} \mathrm{KCl}\end{array}$ \\
\hline A3D2 & $\begin{array}{l}\text { T.viride }+ \text { P.fluorescens }+ \text { Streptomyces } s p \text {. } \\
\text { and doses } 250 \mathrm{~kg} \mathrm{Ha}^{-1} \mathrm{KCl}\end{array}$ \\
\hline A3D3 & $\begin{array}{l}\text { T.viride }+ \text { P.fluorescens }+ \text { Streptomyces } \\
\text { sp.and doses } 375 \mathrm{~kg} \mathrm{Ha}^{-1} \mathrm{KCl}\end{array}$ \\
\hline
\end{tabular}

\section{B. Antagonistic Microbes}

T. viride isolates were grown on PDA (Potato Dextrose Agar) media, Streptomyces sp., and P. fluorescens isolates were grown on Kings B media at $30{ }^{\circ} \mathrm{C}$ for 48 hours. After pure culture was obtained, each was propagated on PDB (potato dextrose broth) media for $T$. viride and Streptomyces sp., While P. fluorescens was propagated with NB (nutrient broth) media and placed in a shaker for 24 hours. The culture that was available was subsequently suspended until it reached a concentration of $10^{8} \mathrm{cfu}_{\mathrm{mL}}^{-1}$ for Streptomyces sp. and P. fluorescens[9] and $10^{7}$ spores. $\mathrm{mL}^{-1}$ for $T$. viride.

Application of antagonistic microbes is done by splashing it on the planting medium as much as $25 \mathrm{ml}$ and given 2 weeks before planting together with the administration of organic material for chicken manure [10]. The second Antagonistic Microbes application was carried out after planting. There are 22 plant populations per plot with a spacing of $30 \times 70 \mathrm{~cm}$. Organic doses of chicken manure used are $15 \mathrm{t} \mathrm{Ha}^{-1}$, inorganic fertilizers given are: urea 300 kg.ha ${ }^{-1}$, TSP $200 \mathrm{~kg} \cdot \mathrm{ha}^{-1}$ and $\mathrm{KCl}$ according to treatment.
TSP fertilizer was applied at the same time as planting, while Urea and $\mathrm{KCl}$ half the dose were applied when the plants were 10 days after planting and half the doses were applied when the plants were 40 days old. Plants are maintained intensively and watered by grazing.

\section{Analysis}

To see the effect of the treatment on the observations made, the observational data were analyzed statistically based on the analysis of variance (ANOVA) and to see the significance continued with the LSD (Least Significance Different)test at a $95 \%$ confidence level.

\section{RESULTS AND DISCUSSION}

\section{A. Plant Height}

The response of plants due to the administration of antagonistic microbes and the application of potassium to plant height did not occur, but separately the types of antagonistic microbes significantly affected at 25, 35, 45, 55 DAP (days after planting). Potassium fertilizer application has a significant effect on all plant ages.

Table 2 shows that the administration of T.viride + Streptomyces sp. + P.fluorescens during plant growth has a tendency to produce higher plant height compared with the administration of P.fluorescens + Streptomyces sp., Although the same response occurs at the age of 45 days after planting. At the age of the plant 55 days after planting, the administration of $P$. flluorescens antagonist independently and in combination with Streptomyces sp. caused a decrease in plant height of $10.43 \%$ and $7.41 \%$.

Plant height in the treatment of antagonistic microbes administration and application of potassium at various plant ages is presented in Table 2 .

Table 2. Plant height after antagonistic microbes and potassium applications

\begin{tabular}{|l|l|l|l|l|l|l|l|}
\hline \multirow{2}{*}{$\begin{array}{c}\text { Treatm } \\
\text { ent }\end{array}$} & \multicolumn{6}{|c|}{ Plant Height (cm) at Various Plant Age (DAP) } \\
\cline { 2 - 8 } & \multicolumn{2}{|c|}{$\mathbf{2 5}$} & \multicolumn{2}{|c|}{35} & \multicolumn{2}{|c|}{$\mathbf{4 5}$} & $\mathbf{5 5}$ \\
\hline Antagonistic microbes \\
\hline A1 & 15.11 & b & 27.47 & a & 44.17 & 65.89 & a \\
\hline A2 & 12.05 & a & 27.45 & a & 42.89 & 68.11 & ab \\
\hline A3 & 16.08 & b & 31.32 & b & 44.23 & 73.56 & b \\
\hline $\begin{array}{l}\text { LSD } \\
5 \%\end{array}$ & \multicolumn{2}{|c|}{1.99} & 3.83 & $\begin{array}{c}\text { Not } \\
\text { really }\end{array}$ & \multicolumn{2}{|c|}{6.15} \\
\hline
\end{tabular}

Potassium Fertilizer dose per Hectare

\begin{tabular}{|l|l|l|l|l|l|l|l|l|}
\hline D1 & 13.34 & $\mathrm{a}$ & 26.92 & $\mathrm{a}$ & 42.54 & $\mathrm{a}$ & 67.67 & $\mathrm{a}$ \\
\hline D2 & 15.76 & $\mathrm{~b}$ & 29.92 & $\mathrm{~b}$ & 45.43 & $\mathrm{~b}$ & 74.01 & $\mathrm{~b}$ \\
\hline D3 & 14.14 & $\mathrm{ab}$ & 29.98 & $\mathrm{~b}$ & 45.41 & $\mathrm{~b}$ & 73.84 & $\mathrm{~b}$ \\
\hline $\begin{array}{l}\text { LSD } \\
\text { 5\% }\end{array}$ & \multicolumn{3}{|c|}{1.82} & 2.94 & \multicolumn{2}{|c|}{2.27} & \multicolumn{3}{|c|}{4.93} \\
\hline
\end{tabular}

te: Numbers accompanied by different letters in the same column show a significantly different level of LSD test at $5 \%$.

Potato plant height during growth is influenced by the dose of potassium fertilizer. Potassium fertilizer $125 \mathrm{~kg} \mathrm{Ha}$ ${ }^{1} \mathrm{KClgives}$ the lowest plant height and is significantly different than the $250 \mathrm{~kg} \mathrm{Ha}^{-1} \mathrm{KCl}$ and $375 \mathrm{~kg} \mathrm{Ha}^{-1} \mathrm{KCl}$. At the age of the plant 55 days after planting, giving $250 \mathrm{~kg}$ 
$\mathrm{Ha}^{-1} \mathrm{KCl}$ of Potassium fertilizer and $375 \mathrm{~kg} \mathrm{Ha}^{-1} \mathrm{KCl}$ markedly increased plant height by $9.37 \%$ and $9.12 \%$.

This happens because the combination of antagonistic microbes in the treatment is able to produce phytohormones such as cytokinins, abscisic acid (ABA) and auxin play an important role in plant development and regulatory processes in plants [11] and its ability to dissolve Phosphate, Nitrogen fixation [12] and stimulate lateral root growth [13].The higher dose of Potassium used up to a dose of $250 \mathrm{~kg} \mathrm{Ha}^{-1} \mathrm{KCl}$ tends to have a significant effect on increasing plant height, a number of leaves and number of branches. This is presumably because $\mathrm{K}$ is able to improve the rate of assimilate translocation that forms plant growth. [14]state that potassium is absorbed in the form of $\mathrm{K}+$. Adequacy of $\mathrm{K}+$ in plants causes plants to grow faster, because one of the functions of potassium is to maintain a constant turgor cell pressure which ultimately stimulates the enlargement of cells that make up the meristem tissue. In line with the statement made [15] that the main function of Potassium for plants is as an activator of various enzymes.

Giving antagonistic microbes also functions as a decomposer of organic matter. The result of the organic material decomposition process is the release of nutrients contained in the organic material. The availability of sufficient nutrients for plant growth causes the metabolic processes that occur in plants to take place normally, so that it will affect the process of photosynthesis and respiration. $P$. fluorescens used in this study had an influence on plant growth (number of leaves, plant height), such as Curcuma longa L [16], Vigna radiate [17]. Streptomyces sp. has the ability to produce acidic and thermostablephytases and plant growth promoting (PGP) properties that show increased plant growth can have implications for acidic soils and also in arid regions [18]. The great potential of $T$. viride biological fertilizer in reducing $\mathrm{NH} 3$ evaporation from alkaline soils and simultaneously increasing the utilization of $\mathrm{N}$ fertilizer by sweet sorghum [18].

\section{B. Number of Leaves}

Table 3. Number of leaves after antagonistic microbes and potassium applications at 35, 45, 55 DAP

\begin{tabular}{|l|l|l|l|l|l|l|}
\hline \multirow{2}{*}{$\begin{array}{c}\text { Treatm } \\
\text { ent }\end{array}$} & \multicolumn{3}{|c|}{ Number of Leaves (Stems) at Age (DAP) } \\
\cline { 2 - 7 } & \multicolumn{2}{|c|}{35} & \multicolumn{2}{c|}{$\mathbf{4 5}$} & \multicolumn{2}{c|}{55} \\
\hline A1D1 & 32.50 & $\mathrm{ab}$ & 56.26 & $\mathrm{a}$ & 117.00 & $\mathrm{a}$ \\
\hline A1D2 & 35.83 & $\mathrm{bc}$ & 62.11 & $\mathrm{bc}$ & 130.97 & $\mathrm{bc}$ \\
\hline A1D3 & 34.72 & $\mathrm{abc}$ & 60.00 & $\mathrm{abc}$ & 131.66 & $\mathrm{bcd}$ \\
\hline A2D1 & 31.06 & $\mathrm{a}$ & 59.28 & $\mathrm{ab}$ & 109.60 & $\mathrm{a}$ \\
\hline A2D2 & 40.22 & $\mathrm{~d}$ & 63.83 & $\mathrm{c}$ & 138.10 & $\mathrm{~cd}$ \\
\hline A2D3 & 37.99 & $\mathrm{~cd}$ & 70.10 & $\mathrm{~d}$ & 133.49 & $\mathrm{bcd}$ \\
\hline A3D1 & 40.11 & $\mathrm{~d}$ & 60.03 & $\mathrm{abc}$ & 126.50 & $\mathrm{~b}$ \\
\hline A3D2 & 40.95 & $\mathrm{~d}$ & 70.10 & $\mathrm{~d}$ & 141.53 & $\mathrm{~d}$ \\
\hline A3D3 & 38.11 & $\mathrm{~cd}$ & 68.83 & $\mathrm{~cd}$ & 138.50 & $\mathrm{~cd}$ \\
\hline LSD & \multicolumn{2}{|c|}{4,20} & \multicolumn{2}{|c|}{4.40} & \multicolumn{2}{|c|}{8.85} \\
5\% & \multicolumn{7}{|c|}{} & \multicolumn{7}{|c|}{} \\
\hline
\end{tabular}

Note: Numbers accompanied by different letters in the same column show a significantly different level of LSD test at $5 \%$.
The number of leaves due to the interaction of antagonistic microbes administration and fertilization of Potassium is presented in Table 3.

Table 3 shows that the interaction of antagonisticmicrobes administration and Potassium dosage at 35 days after planting showed the highest number of leaves achieved in the administration of P.fluorescens + Streptomyces sp. + T.viride at all levels of Potassium fertilizer. These results are the same as the treatment of P.fluorescens + Streptomyces sp. with a dose of Potassium $250 \mathrm{~kg} \mathrm{Ha}^{-1} \mathrm{KCl}$ and $375 \mathrm{kgHa}^{-1} \mathrm{KCl}$.

Age 45 days after planting showed that the highest number of leaves was achieved by antagonizing P.fluorescens + Streptomyces $\mathrm{sp}$. + T.viride with a dose of Potassium $250 \mathrm{~kg} \mathrm{Ha}^{-1} \mathrm{KCl}$ and $375 \mathrm{~kg} \mathrm{Ha}^{-1} \mathrm{KCl}$. These results are the same as the treatment of P.fluorescens + Streptomyces sp. with a dose of Potassium $375 \mathrm{~kg} \mathrm{Ha}^{-1} \mathrm{KCl}$ fertilizer.

Age 55 days after planting showed that the highest number of leaves was achieved by antagonizing P.fluorescens + Streptomyces sp. + T.viridewith a dose of Potassium 250 $\mathrm{kg} \mathrm{Ha}{ }^{-1} \mathrm{KCland} 375 \mathrm{~kg} \mathrm{Ha}^{-1} \mathrm{KCl}$. These results are the same as the treatment of P.fluorescens + Streptomyces sp. with the same dose of Potassium fertilizer and $P$. fluorescens at a dose of $375 \mathrm{kgHa}^{-1} \mathrm{KCl}$. Reducing the dose of Potassium fertilizer to $125 \mathrm{~kg} \mathrm{Ha}^{-1} \mathrm{KCl}$ at 55 days after planting resulted in a decrease in the number of leaves respectively by $17.33 \%, 22.56 \%$ and $10.62 \%$ in P.fluorescens, P.fluorescens + Streptomyces sp. and T.viride + Streptomyces sp. + P.fluorescens.

Separately at the age of 25 days after planting kinds of antagonistic microbes had no significant effect, while the dose of potassium fertilization had a significant effect. Table 4 shows that at the age of 25 days after planting different types of antagonistic microbes gave the same response to the number of leaves. Potassium fertilizer dose $250 \mathrm{~kg} \mathrm{Ha}^{-1} \mathrm{KCland} 375 \mathrm{~kg} \mathrm{Ha}^{-1} \mathrm{KCl}$ produces more leaves than $125 \mathrm{~kg} \mathrm{Ha}^{-1} \mathrm{KCl}$ of Potassium. Reduction of Potassium fertilizer dose to $125 \mathrm{~kg} \mathrm{Ha}^{-1} \mathrm{KCl}$ resulted in a decrease in the number of leaves by $18.09 \%$.

The number of plant leaves in antagonistic microbes and potassium fertilizer application at various plant ages is presented in the Table4.

Table 4. Number of leaves after antagonistic microbes and potassium applications at $25 \mathrm{DAP}$

\begin{tabular}{|c|c|c|}
\hline Treatment & \multicolumn{2}{|c|}{$\begin{array}{c}\text { Number of Leaves (Stems) at Age } \\
25 \text { DAP }\end{array}$} \\
\hline \multicolumn{3}{|c|}{ Antagonistic Microbes } \\
\hline A1 & 16.31 & \\
\hline A2 & 16.81 & \\
\hline A3 & 17.28 & \\
\hline LSD 5\% & \multicolumn{2}{|c|}{ Not really } \\
\hline \multicolumn{3}{|c|}{ Potassium Fertilizer Doses per Hectare } \\
\hline D1 & 15.34 & $\mathrm{a}$ \\
\hline D2 & 18.73 & $\mathrm{~b}$ \\
\hline D3 & 18.44 & $\mathrm{~b}$ \\
\hline LSD 5\% & \multicolumn{2}{|l|}{3.078} \\
\hline
\end{tabular}

Note: Numbers accompanied by different letters in the same column show a significantly different level of LSD test at $5 \%$. 
Not only in potato plants, the application of potassium fertilizer is very important in almost all plants. Potassium (K) plays an important role in the metabolism of carbon (C) and nitrogen $(\mathrm{N})$. The results of research on cotton plants showed that leaf $\mathrm{K}$ content, number of leaves, leaf area, number of boll, reproductive dry weight and total dry weight were significantly lower under K deficiency [19].

\section{Total Main Branch}

The number of main branches due to the interaction of antagonistic microbes administration and fertilization of Potassium is presented in Table 5.

Table 5 shows that the interaction of antagonistic microbes administration and Potassium dose at the age of 25 days after planting shows the highest number of branches achieved in the administration of $P$.fluorescens with a dose of Potassium $250 \mathrm{kgHa}^{-1} \mathrm{KCl}$. These results are the same as the treatment of P.fluorescens + Streptomyces sp. with a dose of Potassium fertilizer $125 \mathrm{kgHa}^{-1} \mathrm{KCl}$ and $250 \mathrm{kgHa}^{-}$ ${ }^{1} \mathrm{KCland}$ P.fluorescens with $250 \mathrm{~kg} \mathrm{Ha}^{-1} \mathrm{KCl}$ of Potassium fertilizer.

Age 35 days after planting showed the highest number of branches achieved in the administration of antagonist P.fluorescens + Streptomyces sp. with a dose of Potassium fertilizer $125 \mathrm{~kg} \mathrm{Ha}^{-1} \mathrm{KCl}$ and $250 \mathrm{kgHa}^{-1} \mathrm{KCl}$. This dose also gives the highest number of main branches and is not significantly different from the previous treatment when given the microbial antagonist $P$. fluorescens. The combination of P.fluorescens + Streptomyces $\mathrm{sp} .+$ T.viride with a dose of Potassium $250 \mathrm{kgHa}^{-1} \mathrm{KCl}$ and $375 \mathrm{kgHa}^{-}$ ${ }^{1} \mathrm{KCl}$ also gave the same response as the previous treatment.

Table 5.Total main branches after antagonistic microbes and potassium applications

\begin{tabular}{|l|l|l|l|l|l|l|l|l|}
\hline \multirow{2}{*}{$\begin{array}{c}\text { Treatm } \\
\text { ent }\end{array}$} & \multicolumn{7}{|c|}{ Total Main Branch at Age (DAP) } \\
\cline { 2 - 9 } & \multicolumn{2}{|c|}{$\mathbf{2 5}$} & \multicolumn{2}{|c|}{$\mathbf{3 5}$} & \multicolumn{2}{|c|}{$\mathbf{4 5}$} & \multicolumn{2}{c|}{$\mathbf{5 5}$} \\
\hline A1D1 & 3.95 & $\mathrm{ab}$ & 3.94 & $\mathrm{ab}$ & 4.31 & $\mathrm{a}$ & 5.00 & $\begin{array}{l}\mathrm{a} \\
\text { b }\end{array}$ \\
\hline A1D2 & 4.33 & $\mathrm{bc}$ & 4.50 & $\mathrm{bc}$ & 4.72 & $\mathrm{ab}$ & 5.10 & $\mathrm{~b}$ \\
\hline A1D3 & 3.78 & $\mathrm{ab}$ & 4.00 & $\mathrm{abc}$ & 4.49 & $\mathrm{ab}$ & 5.10 & $\mathrm{~b}$ \\
\hline A2D1 & 3.72 & $\mathrm{a}$ & 4.95 & $\mathrm{ab}$ & 4.37 & $\mathrm{ab}$ & 4.20 & $\mathrm{a}$ \\
\hline A2D2 & 4.61 & $\mathrm{c}$ & 4.61 & $\mathrm{c}$ & 4.72 & $\mathrm{ab}$ & 5.85 & $\mathrm{c}$ \\
\hline A2D3 & 4.17 & $\mathrm{abc}$ & 3.78 & $\mathrm{a}$ & 4.16 & $\mathrm{a}$ & 5.82 & $\mathrm{c}$ \\
\hline A3D1 & 3.72 & $\mathrm{a}$ & 3.73 & $\mathrm{a}$ & 4.23 & $\mathrm{a}$ & 5.07 & $\mathrm{~b}$ \\
\hline A3D2 & 3.78 & $\mathrm{ab}$ & 3.95 & $\mathrm{abc}$ & 4.95 & $\mathrm{bc}$ & 5.95 & $\mathrm{c}$ \\
\hline A3D3 & 4.17 & $\mathrm{abc}$ & 4.50 & $\mathrm{bc}$ & 5.45 & $\mathrm{c}$ & 5.86 & $\mathrm{c}$ \\
\hline $\begin{array}{l}\text { LSD } \\
\text { 5\% }\end{array}$ & \multicolumn{7}{|c|}{0.55} & \multicolumn{7}{|c|}{0.66} & 0.58 & 0.71 \\
\hline
\end{tabular}

Note: Numbers accompanied by different letters in the same column show a significantly different level of LSD test at $5 \%$.

Age 45 days after planting the combined P.fluorescens + Streptomyces $\mathrm{sp} .+$ T.viride with a dose of Potassium 250 $\mathrm{kgHa}^{-1} \mathrm{KCl}$ and $375 \mathrm{~kg} \mathrm{Ha}^{-1} \mathrm{KCl}$ clearly produced the highest number of branches. Age 55 days after planting the combined P.fluorescens + Streptomyces sp. + T.viride with a dose of Potassium $250 \mathrm{~kg} \mathrm{Ha}^{-1} \mathrm{KCland} 375 \mathrm{kgHa}^{-1} \mathrm{KCl}$ significantly produced the highest number of branches, this dose was not significantly different when combined with the microbial antagonist P.fluorescens + Streptomyces sp.
Reduction of Potassium fertilizer dose to $125 \mathrm{~kg} \mathrm{Ha}$ ${ }^{1} \mathrm{KCl}$ resulted in a decrease in the number of branches by $14.79 \%$ and $28.21 \%$.

Age 45 days after planting the combined P.fluorescens + Streptomyces sp. + T.viride with a dose of Potassium 250 $\mathrm{kgHa}^{-1} \mathrm{KCl}$ and $375 \mathrm{~kg} \mathrm{Ha}^{-1} \mathrm{KCl}$ clearly produced the highest number of branches. Age 55 days after planting the combined P.fluorescens + Streptomyces sp. + T.viride with a dose of Potassium $250 \mathrm{~kg} \mathrm{Ha}^{-1} \mathrm{KCland} 375 \mathrm{kgHa}^{-1} \mathrm{KCl}$ significantly produced the highest number of branches, this dose was not significantly different when combined with the microbial antagonist P.fluorescens + Streptomyces sp. Reduction of Potassium fertilizer dose to $125 \mathrm{~kg} \mathrm{Ha}^{-}$ ${ }^{1} \mathrm{KCl}$ resulted in a decrease in the number of branches by $14.79 \%$ and $28.21 \%$.

The availability of potassium in the soil causes guaranteed plant rigidity and stimulates root growth and will affect the development of plant parts such as the number of leaves, branch growth. In addition, the function of Potassium is to increase nutrient uptake of $\mathrm{N}, \mathrm{P}$ and $\mathrm{K}$ [20, 21, 22].

\section{Potassium Absorption in Plant Leaves}

Potassium uptake in plant leaves due to the interaction of antagonistic microbes administration and potassium fertilization is presented in Table 6 .

Table 6 shows that the interaction between administration of antagonistic microbes and the dose of Potassium fertilizer at 47 days after planting to Potassium uptake in leaves shows variable results. Plants that were given T.viride + P.fluorescens + Streptomyces $\mathrm{sp}$. The highest uptake of Potassium in the leaves was achieved at 250 $\mathrm{kgHa}^{-1} \mathrm{KCland} 375 \mathrm{~kg} \mathrm{Ha}^{-1} \mathrm{KCl}$. Reduction of Potassium fertilizer dose to $125 \mathrm{~kg} \mathrm{Ha}^{-1} \mathrm{KCl}$ in the same antagonist microbes resulted in a decrease in Potassium uptake of $7.81 \%$.Potassium $(\mathrm{K})$ deficiency is a general abiotic stress that can inhibit plant growth and thus reduce plant productivity [23].

Table 6. Potassium uptake in plant leaves after antagonistic microbes and potassium applications at 45 DAP

\begin{tabular}{|l|r|l|}
\hline \multicolumn{1}{|c|}{ Treatment } & $\begin{array}{r}\text { Potassium Absorption in Plant } \\
\text { Leaves }\end{array}$ \\
\hline A1D1 & 2.616 & $\mathrm{a}$ \\
\hline A1D2 & 2.432 & $\mathrm{c}$ \\
\hline A1D3 & 2.500 & $\mathrm{~d}$ \\
\hline A2D1 & 2.171 & $\mathrm{a}$ \\
\hline A2D2 & 2.483 & $\mathrm{~d}$ \\
\hline A2D3 & 2.535 & $\mathrm{e}$ \\
\hline A3D1 & 2.396 & $\mathrm{~b}$ \\
\hline A3D2 & 2.598 & $\mathrm{f}$ \\
\hline A3D3 & 2.599 & $\mathrm{f}$ \\
\hline LSD 5\% & 0.018 \\
\hline
\end{tabular}

Note: Numbers accompanied by different letters in the same column show a significantly different level of LSD test at 5\%.

\section{E. Fresh Weight of Bulb Per Clump}

The fresh weight of bulb per clump due to the interaction of antagonistic microbial administration and potassium fertilizer is presented in Table 7. 
Table 7. Fresh weights of bulb per clump after antagonistic microbes and potassium applications at harvest

\begin{tabular}{|l|r|l|}
\hline \multicolumn{1}{|c|}{ Treatment } & \multicolumn{2}{|c|}{$\begin{array}{c}\text { Fresh Weight of Bulb Per } \\
\text { Clump (gram) }\end{array}$} \\
\hline A1D1 & 265.84 & $\mathrm{a}$ \\
\hline A1D2 & 326.75 & $\mathrm{ab}$ \\
\hline A1D3 & 325.73 & $\mathrm{~d}$ \\
\hline A2D1 & 264.00 & $\mathrm{a}$ \\
\hline A2D2 & 292.40 & $\mathrm{ab}$ \\
\hline A2D3 & 299.25 & $\mathrm{bc}$ \\
\hline A3D1 & 274.87 & $\mathrm{ab}$ \\
\hline A3D2 & 373.87 & $\mathrm{~d}$ \\
\hline A3D3 & 365.86 & $\mathrm{~d}$ \\
\hline LSD 5\% & \multicolumn{3}{|c|}{28.73} \\
\hline
\end{tabular}

Note: Numbers accompanied by different letters in the same column show a significantly different level of LSD test at $5 \%$.

Table 7 shows that the interaction between antagonistic microbial administration and the dosage of Potassium fertilizer on the fresh weight of bulb per clump at harvest shows variable results. The highest fresh tuber weight per clump was achieved in the administration of T.viride + P.fluorescens + Streptomyces sp. and a dose of Potassium $250 \mathrm{~kg} \mathrm{Ha}{ }^{-1} \mathrm{KCl}$ and $375 \mathrm{kgHa}^{-1} \mathrm{KCl}$, which was not significantly different if the plants were given antifungal microbial P.fluorescens and a dose of Potassium $375 \mathrm{~kg}$ $\mathrm{Ha}^{-1} \mathrm{KCl}$

Reduction of Potassium fertilizer dose to $125 \mathrm{kgHa}^{-1} \mathrm{KCl}$ in T.viride + P.fluorescens + Streptomyces sp. resulting in a decrease in fresh weight of bulb per clump by $24.87 \%$ and $27.59 \%$ in the antagonist microbial P.fluorescens. TheN and $\mathrm{K}$ fertilization provides good nutrition for the growth of amaryllis flowers (Hippeastrum spp.). Amaryllis flower production is strongly influenced by tuber size [24].

\section{F. Fresh Weight of Bulb per Hectare}

The fresh weight of bulb per hectare due to the interaction of antagonistic microbial administration and the application of Potassium is presented in Table 8 .

Table 8. Fresh weight of bulb per hectare after antagonistic microbes and potassium applications at harvest

\begin{tabular}{|l|l|l|}
\hline \multicolumn{1}{|c|}{ Treatment } & \multicolumn{2}{|c|}{$\begin{array}{c}\text { Fresh Weight of Bulb Per } \\
\text { Hectare (ton/hectar) }\end{array}$} \\
\hline A1D1 & 10.1270 & $\mathrm{a}$ \\
\hline A1D2 & 12.4477 & $\mathrm{c}$ \\
\hline A1D3 & 12.4087 & $\mathrm{c}$ \\
\hline A2D1 & 10.0570 & $\mathrm{a}$ \\
\hline A2D2 & 11.1390 & $\mathrm{ab}$ \\
\hline A2D3 & 11.4003 & $\mathrm{bc}$ \\
\hline A3D1 & 10.4713 & $\mathrm{ab}$ \\
\hline A3D2 & 14.2427 & $\mathrm{~d}$ \\
\hline A3D3 & 13.9373 & $\mathrm{~d}$ \\
\hline LSD 5\% & 1.0947 & \\
\hline
\end{tabular}

Note: Numbers accompanied by different letters in the same column show a significantly different level of LSD test at $5 \%$.

Table 8 shows that the interaction between antagonistic microbial administration and the dosage of Potassium fertilizer to the fresh weight of bulb per hectare at harvest shows varied results. The highest fresh tuber weight per hectare was achieved in the administration of T.viride + P.fluorescens + Streptomyces sp. and a dose of Potassium $250 \mathrm{~kg} \mathrm{Ha}^{-1} \mathrm{KCl}$ was not significantly different from the $375 \mathrm{kgHa}^{-1} \mathrm{KCl}$. Reduction of Potassium fertilizer dose to $125 \mathrm{kgHa}^{-1} \mathrm{KCl}$ in T.viride + P.fluorescens + Streptomyces sp. resulting in a decrease in tuber fresh weight per hectare by $26.48 \%$. The results obtained indicate that one of the functions of $\mathrm{K}+$ is as nutrient transport, water and photosynthesis results. With the increase in the provision of $\mathrm{KCl}$ fertilizer, the results that are transported to the bulb also increase. These results are in accordance with research [25], which states that potato plants fertilized with 250 $\mathrm{kgHa}^{-1} \mathrm{KClproduce}$ the most bulb per hectare.

\section{G. Percentage of Dry Weight of Bulb When \\ Harvesting}

The percentage of dry weight at harvest due to the interaction of antagonistic microbial and potassium fertilization is presented in Table 9.

The highest percentage of tuber dry weight at harvest was achieved in the administration of T.viride + P.fluorescens + Streptomyces sp. and a dose of Potassium $250 \mathrm{kgHa}$ ${ }^{1} \mathrm{KClwas}$ not significantly different from the $375 \mathrm{kgHa}$ ${ }^{1} \mathrm{KCl}$ dose. Reduction of Potassium fertilizer dose to 125 $\mathrm{kgHa}^{-1} \mathrm{KClin}$ T.viride + P.fluorescens + Streptomyces $\mathrm{sp}$. resulting in a decrease in tuber dry weight of $12.63 \%$. According to [26], based on conducted research on the administration of $\mathrm{N}, \mathrm{P}, \mathrm{K}, \mathrm{Ca}, \mathrm{Mg}, \mathrm{S}, \mathrm{As}, \mathrm{Cd}, \mathrm{Cr}, \mathrm{Cu}, \mathrm{Fe}$, $\mathrm{Mn}, \mathrm{Ni}, \mathrm{Pb}$ and $\mathrm{Zn}$ in potato plants, the results obtained by production efficiency much higher recorded for mineral fertilizers $\mathrm{N}, \mathrm{P}$ and $\mathrm{K}$.

Table 9. Interaction between antagonistic microbial and Potassium fertilizer at harvest

\begin{tabular}{|l|r|l|}
\hline \multicolumn{1}{|c|}{ Treatment } & $\begin{array}{r}\text { Percentage of Dry Weight of } \\
\text { Bulb (\%) }\end{array}$ \\
\hline A1D1 & 11.703 & b \\
\hline A1D2 & 12.210 & bc \\
\hline A1D3 & 12.917 & de \\
\hline A2D1 & 10.293 & a \\
\hline A2D2 & 12.523 & cd \\
\hline A2D3 & 12.930 & de \\
\hline A3D1 & 11.873 & b \\
\hline A3D2 & 13.240 & ef \\
\hline A3D3 & 13.590 & f \\
\hline LSD 5\% & \multicolumn{3}{|c|}{0.632} \\
\hline
\end{tabular}

Note: Numbers accompanied by different letters in the same column show a significantly different level of LSD test at $5 \%$.

\section{H. Weight Bulb at Harvest}

The percentage of bulb dry weight at harvest due to the interaction of antagonistic microbial and potassium fertilization is presented in Table 10 .

Table 10 shows that the interaction between antagonistic microbial administration and dosage of Potassium fertilizer on tuber specific gravity at harvest shows varied results. The highest percentage of tuber specific gravity at harvest was achieved by the administration of T.viride + P.fluorescens + Streptomyces sp. and a dose of Potassium 
$250 \mathrm{kgHa}^{-1} \mathrm{KClwas}$ not significantly different from the 375 $\mathrm{kgHa}^{-1} \mathrm{KCl}$. Reduction of Potassium fertilizer dose to 125 $\mathrm{kg} \mathrm{Ha}{ }^{-1} \mathrm{KClin}$ T.viride + P.fluorescens + Streptomyces $\mathrm{sp}$. tuber dry weight resulted in a decrease of $8.97 \% .8 .97 \%$. Giving KNO3 has a good effect on the productivity of onion bulb[27].

Table 10. Weight bulb after antagonistic microbial and Potassium fertilizer at harvest

\begin{tabular}{|l|r|l|}
\hline \multicolumn{1}{|c|}{ Treatment } & Tuber Specific Gravity $\left(\mathbf{g ~ c c}^{-1}\right)$ \\
\hline A1D1 & 0.920 & a \\
\hline A1D2 & 0.957 & b \\
\hline A1D3 & 0.973 & bc \\
\hline A2D1 & 0.953 & b \\
\hline A2D2 & 0.970 & bc \\
\hline A2D3 & 0.970 & bc \\
\hline A3D1 & 0.913 & a \\
\hline A3D2 & 0.983 & cd \\
\hline A3D3 & 1.003 & d \\
\hline LSD 5\% & \multicolumn{3}{|c|}{0.024} \\
\hline
\end{tabular}

Note: Numbers accompanied by different letters in the same column show a significantly different level of LSD test at 5\%.

\section{Reduced Sugar Levels}

The percentage of reduced sugar levels due to the interaction of antagonistic microbial administration and fertilizer application of Potassium is presented in Table 11.

Table 11. Reduced sugar levels (\%) due to the interaction of antagonistic microbial and the dose of Potassium fertilizer at harvest

\begin{tabular}{|l|r|l|}
\hline \multicolumn{1}{|c|}{ Treatment } & \multicolumn{2}{c|}{ Reduced Sugar Levels (\%) } \\
\hline A1D1 & 0.06343 & ab \\
\hline A1D2 & 0.06230 & a \\
\hline A1D3 & 0.06270 & a \\
\hline A2D1 & 0.06270 & a \\
\hline A2D2 & 0.06493 & bc \\
\hline A2D3 & 0.06570 & cd \\
\hline A3D1 & 0.06683 & de \\
\hline A3D2 & 0.06887 & f \\
\hline A3D3 & 0.06837 & ef \\
\hline LSD 5\% & \multicolumn{2}{|c|}{0.00168} \\
\hline
\end{tabular}

Note: Numbers accompanied by different letters in the same column show a significantly different level of LSD test at $5 \%$.

Table 11 shows that the interaction between antagonistic microbial administration and dosage of Potassium fertilizer on tuber-reduced sugar levels at harvest shows variable results. The highest sugar-reduced tuber levels at harvest were achieved with the administration of T.viride + P.fluorescens + Streptomyces sp. and a dose of Potassium $250 \mathrm{kgHa}^{-1} \mathrm{KCl}$ was not significantly different from the 375 $\mathrm{kg} \mathrm{Ha}{ }^{-1} \mathrm{KCl}$. Reduction of Potassium fertilizer dose to 125 $\mathrm{kgHa}^{-1} \mathrm{KClin}$ T.viride + P.fluorescens + Streptomyces $\mathrm{sp}$. Result in a decrease in tuber reduced sugar levels by $2.96 \%$.

Increasing the amount of antagonistic microbial diversity and dosage of Potassium fertilizer indicates that the role of $\mathrm{K}$ in the physiological processes of plants runs well which includes: enhancement and development of plant tissue through simple sugar synthesis, starch, carbohydrate translocation and protein synthesis [28]. Thus the process of photosynthesis can run optimally.

\section{CONCLUSION}

Provision of P.fluorescens + Streptomyces sp. + T. viride and $250 \mathrm{~kg} \mathrm{Ha}^{-1} \mathrm{KCl}$ and $375 \mathrm{~kg} \mathrm{Ha}^{-1} \mathrm{KCl}$ doses tend to produce growth, tuber fresh weight per hectare, tuber dry weight percentage, tuber specific gravity and higher sugar content than other treatments.

\section{ACKNOWLEDGMENT}

This research was funded byThe Indonesian Ministry of Research, Technology and Higher Education (Ristekdikti) with a research grant PTUPT.Thanks for the assistance provided so that this research can be useful.

\section{REFERENCES}

[1] W. Zhang, X. Liu, Q. Wang, H. Zhang, M. Li, B. Song, Z. Zhao, "Effects of potassium fertilization on potato starch pjysicochemical properties," International Journal of Biological Macromolecules, vol. 117, pp 467-472, May 2018.

[2] N. K. Fageria, M. P. D. Filho, J. H. C. Da Costa, "Potassium use efficiency in common bean genotype", J. Plant Nutr, vol. 24, pp. 1937-1945, 2001.

[3] E. Liljeroth, A. Lankinen, L. Wiik, D. D. Burra, E. Alexandersson, E. Andreasson, "Potassium phosphite combined with reduced doses of fungicides provides efficient protection against potato late blight in large-scale field trials", Crop Protection, vol. 86, pp. 42-55, April 2016.

[4] Marsono, P. Sigit, "Petunjuk pemupukan yang efektif", Agromedia Pustaka. Jakarta.

[5] C. Zorb, M. Senbayram, E. Peiter, "Potassium in agriculture- Status and perspectives", Journal of Plant Physiology, vol. 171, pp. 656-669, October 2013.

[6] Z. Lu, W. Hu, T. Ren, C. Zhu, X. Li, R. Cong, S. Guo, J. Lu, "Impact of $\mathrm{K}$ deficiency on leaves and siliques photosyntehsis via metabolomics in Brassica napus", Environmental and Experimental Botany, vol. 158, pp. 89-98, February 2019.

[7] T. Wardiyati, M. Dawam, M. Rofiq, "Teknologi budidaya kentang dataran medium di Jawa Timur", Jurnal Cakrawala, vol. 10, pp. 81-88, Juni 2016.

[8] D. Ristikawati, "Respon pertumbuhan dan hasil kentang (Solanum tuberosum L.) dataran medium varietas DTO 28 terhadap dosis pupuk NPK dan PGPR", Skripsi, Universitas Brawijaya.

[9] Nurbaya, T. Kuswinanti, Baharuddin, "Bacterial antagonist isolates in controlling bacterial wilt 
disease of potato (Ralstonia solanacearum) in Aeroponis cultivation system", International Journal of Agriculture Systems (IJAS), vol. 1, Issue 1, June 2013.

[10] A. Rosyidah,"Uji antagonisme beberapa mikroba pengendali hayati terhadap penyebab layu bakteri $(R$. solanacearum) secara in vitro". Belum dipublikasikan, 2012.

[11] K. E. High, P. D. Ashton, M. Nelson, E. L. Rylott, J. E. Thomas-Oates, M. E. Hodson, "New approaches using mass spectrometry to investigate changes to cytokinin and abscisic acid (ABA) concentrations in soil", Soil Biology and Biochemistry, vol. 135, pp. 108-116, April 2019.

[12] D. Thakuria, N. C. Talukdar, C. Goswani, S. Hazarika, R. C. Boro, "Characterization and screening of bacteria from rhizosphere of rice grown in acidic soils of Assam". Current Science, vol.83, pp. 1140-1143, 2014.

[13] P. Vasudevan, M. S. Reddy, S. Kavitha, P. Velusamy, R. S. D Paulraj, "Role of biological preparations in enhancement of rice seedling growth and grain yield", Current Science, vol. 83, pp. 1140-1143, 2002.

[14] A. Haris S., V. Krestiani, "Studi pemupukan kalium terhadap pertumbuhan dan hasil jagung manis (Zea mays saccharata Sturt) varietas super bee", ISSN: 1979-6870, 2009.

[15] M. Rauf, M. Munir, M. Hassan, M. Ahmed, M. Afzal, "Performance of wheat genotypes under osmotic stress at germination and early seedling growth stage", African Journal of Biotechnology, vol. 8, pp. :971-975, 2007.

[16] A. Kumar, Vandana, M. Signh, P. P. Singh, S. K. Singh, P. K. Singh, K. D. Pandey, "Isolation of plant growth promoting rhizobacteria and their impact on growth and curcumin content in Curcuma longa L", Biocatalysis and Agricultural Biotechnology, July 2016.

[17] M. K. Sipahutar, J. Piapukiew, A. S. Vangnai, "Efficiency of the formulated plant-growth promoting Pseudomonas fluorescens MC46 inoculant on triclocarban treatment in soil and its effect on Vigna radiata growth and soil enzyme activities", Journal of Hazardous Materials, vol. 344, pp. 883-892, November 2017.

[18] K. R. Puppala, K. Bhavsar, V. Sonalkar, J. M. Khire, M. S. Dharne, "Characterization of novel acidic and thermostable phytase secreting Streptomyces sp. (NCIM 5533) for plant growth promoting characteristics", Biocatalysis and Agricultural Biotechnology, January 2019.
[19] X. Wang, S. Xu, S. Wu, S. Fang, Z. Bai, G. Zhuang, X. Zhuang, "Effects of Trichoderma virid biofertilizer on ammonia volatilization from an alkaline soil in Northern China", Journal of Environmental Sciences, vo. 66, pp. 199-207, May 2017.

[20] W. Hu, T. D. Coomer, D. A. Loka, D. M. Oosterhuis, Z. Zhou, "Potassium deficiency affects the carbon-nitrogen balance in cotton leaves", Plant Physiology and Bichemistry, vol. 115, pp. 408-417, April 2017.

[21] J. Liu, T. Yin, B. Tian, B. Zhang, C. Qian, Z. Wang, L. Zhang, P. Liang, Z. Chen, J. Yan, X. Fan, J. Lin, X. Chen, Y. Huang, K. P. Loh, Z. X. Shen, "Unraveling the potassium storage mechanism in graphite foam", Advanced Energy MaterialsVolume 9, Issue 22, April 2019.

[22] Ch. Srinivasarao, B. Reddy, S. Kundu,"Potassium nutrition and management in Indian agriculture". Indian J. Fert. Vol. 10, pp. 58-80, 2014.

[23] M. A. Aziz, T. A. Amees, Raina, Bharti, Pharande, A.L., Ali, Tahir, 2013." Influence of potassium application in conjunction with FYM on growth, yield and quality of chickpea in shrink swell soil series", Progress. Agric. vol. 13, pp 151-155, 2013.

[24] M. Wang, Q. Zheng, Q. Shen, S. Guo, " The critical role of potassium in plant stress response", International Journal of Molecular Science, vol. 14, pp. 7370-7390, April 2013.

[25] M. Silberbush, J. E. Epharath, Ch. Alekperov, J. Ben-Asher, "Nitrogen and potassium fertilization interactions with carbon dioxide enrichment in Hippeastrum bulb growth', Scientia Horticulturae, vol. 98, pp. 85-90, November 2002.

[26] N. Gunadi, "Effect of dosage potassium fertilizer on the potato growth and results". Proceedings, 1: 134-150, 2009.

[27] W. Grzebisz, P. Cermak, E. Rroco, W. Szczepaniak, J. Potarzycki, G. Fuleky, "Potassium impact on nitrogen use efficiency in potato a case study from the Central-East Europe, Plant Soil Environ, vo. 63, pp. 422-427, 2017.

[28] M. Perez-Jimenez, M. Pazos-Navarro, J. LopezMarin, A. Galvez, P. Varo, F. M. del Amor, "Foliar application of plant growth regulators changes the nutrient composition of sweet pepper (Capsicum annuum L.)", Scientia Horticulturae, vol. 194, pp. 188-193, August 2015. 